\title{
EVALUATION OF AN OPTIMAL PRODUCTIVITY CROP PRODUCTION INDEX AS A RESULT OF SALINITY AND SODICITY CONTROL OF ALLUVIAL SOILS OF WEST NILE NUBIAN PLANTS
}

\section{EVALUACIJA OPTIMALNOG INDEKSA BILJNE PROIZVODNJE KAO REZULTATA KONTROLE SALINITETA I ALKALITETA ALUVIJALNIH ZEMLJIŠA ZAPADNE NILE NUBIAN DOLINE}

\author{
Žeželj Branislav', Hojka Zdravko² \\ ${ }^{1}$ Megatrend University, Faculty for Bio farming, M.Tito no.39, 24300 Backa Topola, Serbia \\ 2"Meling" Ltd. Comp. Owner-Manager, Marsala Tolbuhina no. 13, 11080, Belgrade-Zemun, Serbia \\ e-mail: melingzezelj@gmail.com
}

\section{SUMMARY}

Soluble salts commonly encountered in salt-affected soils include those of alkaline metals (sodium and potassium) and alkaline earth metals (calcium and magnesium). Some of these salts are sparingly soluble (carbonates of calcium and magnesium), others are slightly soluble (calcium sulphates) and yet others are moderately to highly soluble (chlorides, nitrates and bicarbonates of calcium and magnesium and all salts of sodium and potassium). The study area has been divided into classes of salinity and sodicity

Critical salinity (ECe) and sodicity (SAR) levels have been set for the range of crops being contemplated for the study area. Assuming that a potential yield reduction of $25 \%$ is the maximum reduction that could be tolerated for most of the crops, then the permissible ECe level should not be more than $12 \mathrm{dSm}^{-1}$ and the permissible SAR values should not be more than 24. It is worth mentioning that even at these ECe and SAR values some of the salt sensitive crops might suffer from a reduction in yield that can amount up to $50 \%$. On the other hand, salt tolerant crops will be little affected.

Just as crops differ in tolerance to high salt concentrations, they also differ in their ability to withstand high sodium concentrations. Crop growth and development problems on sodic soils can be nutritional (sodium accumulation by plants), associated with poor soil physical conditions, or both. Plants on sodic soils usually show a burning or drying of tissue at leaf edges, progressing inward between veins. General stunting is also common. Crops differ in their ability to tolerate sodicity, but if sodium levels are high enough, all crops can be affected. Generally, soybeans are quite sensitive, corn and grain sorghum are intermediate and wheat and alfalfa are more tolerant. Few sorghum-Sudan hybrids are very tolerant, able to grow on soils with exchangeable sodium percentages above $50 \%$. The above mentioned assumptions are even more important when one has in mind the fact that the Norht Sudan State has more than 16 million ha of arable land areas.

Key words: Salinity control, sodicity control, reclamation production, salt leaching, suitabiliy cll. 


\section{INTRODUCTION}

The problem of desalinization of highly saline soils has drawn significant attention of researchers, not only in past, but at present time, too. Having in mind the wide area of "unproductive" lands, it's obvious that only the minor part has been reclaimed.

The majority of scientific researchers have been realized within the territory of Republic of Iraq (South-East Mesopotamia), where the most of the investigations has been organized.

Besides Iraqis, Dutch, Russian and American, a research activity has been dominantly established by the Serbs. Halomorphic soils of Serbia, the same as the equivalent once in the world, engrossed the significant vigilance of Serbian science. Part of examinations has escorted in field of chemical amelioration by gypsum and lime and their influence to chemical characteristics of "Slatine".

Following 2 year Land Reclamation period the physical-chemical and biological soil properties are considerable improved, providing their transfer toward the "Normal Soils", were cultivation of sustainable agriculture production may take place.

Regardless the significant scientific results attained in field of Land Reclamation all over the world where experimental examination took place, it's quite obvious that only the inconsiderable researchers have engaged economical dimension as a fundamental basis for the final selection of certain reclamation methods.

The subjective analysis, obtained and presented results referred to applied models of reclamation production, represents the integral part of the complete experimental investigations.

Having in mind the above mentioned, the Final Selection of the reclamation crop production optimal models has been based on:

A. Production economical analysis of chosen crops tolerant to high salts content as a basis for Crop Rotation Models Selections.

B. Economical analyses of Land Cultivation (Mechanical Reclamation), technology varieties applied.

C. Economical-financial analysis of the irrigation methods applied during the reclamation crop production period.

In accordance to the objective analyses, within 9 reclamation crops economically evaluated, three Crop Rotation Models, based on a three reclamation crops (Barley, Sweet clover and Sudan grass), have been emphasized and recommended.

Basically, the obtained and presented analysis results represent integrative input components estimation-gross expenses per ha, for each defined and selected reclamation production crop rotation model.

\section{MATERIALS AND METHODS}

In desert and semi-desert regions, including the study area (West Nile Nubian Plains), the major concern, with respect to salt affected soils, is salinity and sodicity. A soil is considered saline if the electrical conductivity $\left(\mathrm{EC}_{\mathrm{e}}\right)$ of its saturation extract has a value $>4 \mathrm{dS} / \mathrm{m}$. Values of $E_{\mathrm{e}}>1 \mathrm{dS} / \mathrm{m}$ are usually encountered in the soils of the arid and semi-arid regions. In such regions the climate is characterized by annual potential evapotranspiration rates that exceed by far precipitation (Van der Kevie, 1976), released into solution through weathering or as a result of intrusion of saline water tend to accumulate in the form of secondary minerals in these soils as they dry out. The secondary 
minerals include the clay minerals, carbonates, chlorides and sulfates. The cations $\mathrm{Na}^{+}$, $\mathrm{K}^{+}, \mathrm{Ca}^{++}$and $\mathrm{Mg}^{++}$can be easily brought into solution; therefore they contribute most to salinity. Therefore, the dominant salts in the soils of the arid and semi-arid regions are those of $\mathrm{CO}_{3}^{--}, \mathrm{SO}_{4}^{--}$and $\mathrm{Cl}^{-}$.

High salinity (Total soluble salt content) causes reduction in the water potential of the soil solution (osmotic effect) and also concentration of some toxic ions that interfere with normal metabolism of the plants (specific ion effect). The reduction of the osmotic potential (which is a component of the total water potential) increases the effort exerted by the plant to exclude salts from being absorbed, thereby increasing the stress on the plant (physiological stress or drought). The common toxicity resulting from specific ion effect in the soils of arid and semi-arid regions includes chloride, sodium and boron.

Sodicity (concentration of exchangeable $\mathrm{Na}+$ ions) causes deterioration of the soil structure and possible sodium toxicity to plants. Two active mechanisms are involved: swelling and shrinkage. When the levels of exchangeable sodium are low (5 - 15\%), sodium can be adsorbed on the external exchange sites of the tactoids (micro clay platelets) of the calcium-saturated montmorillonite clay minerals while calcium ions remain adsorbed on the internal surfaces. (FAO 1976). Neighboring cations repel each other as a result of the electric double diffused layer around each tactoid. Dispersion occurs when salinity is low. The dispersed tactoids can migrate and clog the soil pores thereby reducing the hydraulic conductivity. When exchangeable sodium ions are relatively high $(25-30 \%)$ swelling of the soil becomes apparent as a result of the adsorption of the sodium ions in the internal surfaces of the tactoids. In that case the number of monovalent cations that can occupy internal surfaces of the clay platelets exceeds that of the divalent cations (e.g. $\mathrm{Ca}^{++}$) which occupy the same surface area. This will result in increase in the osmotic pressure through induction of water movement in the direction of the interlayer lattice of the platelets causing eventually swelling of the clay. At very high exchangeable sodium percentages (> 50\%) swelling becomes so high to the extent that the repulsive forces of the electric double layer lead to the deterioration of the structure of the tactoids resulting in the dispersion of the lay system.

The classification of saline soils reflects the types and quantities of salts present in the soil and the consequent limitations that these salts can cause to plant growth and land use. The electrical conductivity of the soil saturation extract (ECe) at $25^{\circ} \mathrm{C}$ is a measure of the total soluble salt content of the soil solution (saturation extract) and is, therefore, used as an indicator of the soil salinity (Page, A.L. at all). Its use depends on the dissociation of the salts (electrolytes) in water. Since ions are good conductors of electric current, the electrical conductivity of a solution reflects its salt content so that as salt content of the solution increases the electrical conductivity will increase.

The definitive criteria used for the classification of sodic soils is the exchangeable sodium percentage (ESP) defined as:

$\mathrm{ESP}=100(\mathrm{NaX} / \mathrm{CEC})$

Where:

ESP $=$ exchangeable sodium percentage

$\mathrm{NaX}=$ exchangeable sodium expressed as $\mathrm{Cmole}^{+} / \mathrm{kg}$ soil .

$\mathrm{CEC}=$ cation exchange capacity expressed as $\mathrm{Cmole}^{+} / \mathrm{kg}$ soil. 
An alternative measure of sodicity is sodium adsorption ratio (SAR) which is a more easy-to-determine property as compared with ESP. SAR is calculated in the saturation extract as follows:

$$
\mathrm{SAR}=\mathrm{Na} / \sqrt{ }(\mathrm{Ca}+\mathrm{Mg}) / 2)
$$

Where $\mathrm{Na}, \mathrm{Ca}$ and $\mathrm{Mg}$ are the soluble forms expressed in $\mathrm{mmol}^{+} / \mathrm{L}$.

The precipitation and accumulation of salts in the soils of the arid regions is a direct result of the following:

The $\mathrm{pH}$ of the soils of the study area is alkaline. This, of course, is not unexpected for soils that have formed (and still are forming) under arid/semi-arid climate.

The FAO framework of land evaluation is used in the Sudan. Four categories, namely, Orders, Classes, Subclasses and Units are recognized in the FAO System (1976).

I. Land Suitability Orders: Orders reflect kinds of suitability (i.e. Suitable (S) and Not Suitable (N);

II. Land Suitability Classes: Classes reflect degrees of suitability within orders (i.e. S1, S2, S3, N1 and N2);

III. Land Suitability Subclasses: Reflect kinds of limitation or kinds of inputs and improvements required within classes (i.e. S2d, etc.);

IV. Land Suitability Units: Reflect minor differences in the required management within subclasses (e.g. S2d-2, etc.).

Disposition of the of the framework of land evaluation of land suitability will be discussed in the follows chapter

Table 1. Area and percent of different land suitability classes in the study area

\begin{tabular}{l|lll} 
Land suitability subclass & Area $(\mathrm{Ha})$ & Area $(\mathrm{Fed})$ & $\%$ \\
\hline S3df & 54.8 & 130.4 & 8.1 \\
S3dfs & 118.0 & 281.2 & 17.5 \\
S2f & 270.9 & 645.1 & 40.1 \\
S2fg & 68.7 & 163.5 & 10.2 \\
sodicityS2fgs & 33.4 & 79.6 & 4.9 \\
S2fs & 129.5 & 308.3 & 19.2
\end{tabular}

The following statement can be drawn from table 1.:

$75 \%$ of the soils of the study area are S2.

$25 \%$ of the soils of study area are S3.

The main limitations of land suitability are the fertility followed by salinity, gravel and shallow depth.

\section{RESULTS AND DISCUSSIONS}

Soluble salts commonly encountered in salt-affected soils include those of alkaline metals (sodium and potassium) and alkaline earth metals (calcium and magnesium). Some of these salts are sparingly soluble (carbonates of calcium and magnesium), others are slightly soluble (calcium sulphates) and yet others are moderately to highly soluble (chlorides, nitrates and bicarbonates of calcium and magnesium and all salts of sodium and potassium). 
The study area has been divided into classes of salinity and sodicity according to criteria presented in Table 1. and Tabl 2. respectively.

Table 1. Salinity classes

$\begin{array}{lll}\text { Salinity class code } & \begin{array}{l}\text { Salinity class name } \\ \text { ECe }(\mathrm{dS} / \mathbf{m}) \\ \text { in } \mathbf{0 - 1 0 0} \mathrm{cm} \text { soil depth }\end{array} \\ \mathbf{1} & \text { Non-saline } & <\mathbf{4} \\ \mathbf{2} & \text { Slightly saline } & \mathbf{4}-\mathbf{8} \\ \mathbf{3} & \text { Moderately saline } & \mathbf{8}-\mathbf{1 2} \\ \mathbf{4} & \text { Saline } & \mathbf{1 2}-\mathbf{1 6} \\ \mathbf{5} & \text { Very saline } & \mathbf{1 6}-\mathbf{3 2} \\ \mathbf{6} & \text { Extremely saline } & \mathbf{> 3 2}\end{array}$

Table 2. Sodicity classes

\begin{tabular}{|c|c|c|}
\hline Sodicity class code & Sodicity class name & $\begin{array}{l}\text { SAR }\left(\mathrm{mmol}^{+} / \mathrm{L}\right)^{1 / 2} \\
\text { in } 0-100 \mathrm{~cm} \text { soil depth }\end{array}$ \\
\hline 1 & Non-sodic & $<13$ \\
\hline 2 & Slightly sodic & $13-23$ \\
\hline 3 & Sodic & $23-33$ \\
\hline 4 & Strongly sodic & $33-48$ \\
\hline 5 & Very strongly sodic & $>48$ \\
\hline
\end{tabular}

Critical salinity (ECe) and sodicity (SAR) levels have been set for the range of crops being contemplated for the study area. Assuming that a potential yield reduction of $25 \%$ is the maximum reduction that could be tolerated for most of the crops, then the permissible ECe level should not be more than $12 \mathrm{dSm}^{-1}$ and the permissible SAR values should not be more than 24. It is worth mentioning that even at these ECe and SAR values some of the salt sensitive crops might suffer from a reduction in yield that can amount up to $50 \%$. On the other hand, salt tolerant crops will be little affected.

Values of ECe and SAR higher than the above set critical values might be allowed provided that soil reclamation prior to cultivation had been put into effect. The Soils that need reclamation were delineated on the basis of laboratory data of both soil profiles and auger samples.

Crops differ in their ability to tolerate salt accumulation in soils, but if levels are high enough (> $16 \mathrm{dS} / \mathrm{m})$ only tolerant plants will survive. As salts accumulate in soil, the osmotic pressure of the soil solution will increase. When this happens, the amount of water available for plant uptake decreases and plants exhibit poor growth and wilting even though the soil is not dry. Crop selection can be a good management tool for moderately saline soils. Table 5.3 serves as a general guide of salt tolerance ratings for crops, realizing that management practices, irrigation water quality, environment, and crop variety also affect tolerance. 
Table 3. Salt tolerance ratings for various fields and forage crops

Sensitive

$(0-4 \mathrm{dS} / \mathrm{m})$
Moderately

Tolerant

(4-6 dS/m)
Tolerant

(6-8 dS/m)
Highly Tolerant

(8-12 dS/m)
Wheat

Oats

Triticale

Sunflower

Alfalfa

Tall Fescue

Sweet

Clovers

Just as crops differ in tolerance to high salt concentrations, they also differ in their ability to withstand high sodium concentrations. Crop growth and development problems on sodic soils can be nutritional (sodium accumulation by plants), associated with poor soil physical conditions, or both. Plants on sodic soils usually show a burning or drying of tissue at leaf edges, progressing inward between veins. General stunting is also common. Crops differ in their ability to tolerate sodicity, but if sodium levels are high enough, all crops can be affected. Generally, soybeans are quite sensitive, corn and grain sorghum are intermediate and wheat and alfalfa are more tolerant. Few sorghum-Sudan hybrids are very tolerant, able to grow on soils with exchangeable sodium percentages above 50 percent.

The distribution of salinity and sodicity in the survey area is shown in maps 2, taking into consideration the weighted values in the top $100 \mathrm{~cm}$. This map was compiled on the basis of ECe and SAR by overlaying values of these two parameters for all auger sites on the map of the whole area.

Table 4. Extent and percent of salinity/sodicity classes

$\begin{array}{cccc}\text { Class } & \text { Area (ha) } & \text { Area (fed) } & \% \\ \text { Non-saline/non-sodic } & 396.3 & 943.5 & 58.7 \\ \text { Slightly saline/Non-sodic } & 263.3 & 626.9 & 39.0 \\ \text { Moderately saline/ Non- sodic } & 15.8 & 37.6 & 2.3\end{array}$

Leaching of salt beyond the rooting zone is crucial for reclamation of the saline soils, since the River Nile is the contemplated source of irrigation water for the proposed project, the salinity of the soils will continue to decrease following irrigation with good quality irrigation water until the salinity of the soil solution strikes equilibrium, at least within the rooting zone (Whiteman A.J 1971).

Many of the existing soil conditions have been recorded during the soil surveys. They have dealt with the present status and, to a certain extent, with an assessment of soil fertility. There is little biological activity, a consequence of very low rainfall and very high soil temperatures. Organic matter content is, as expected, also very low. Consequently surface soil structure is weak to non-existent. 
There is a need to stabilize and improve the topsoil structure and increase biological activity. The addition of animal manure or compost, or indeed any other organic matter source such as a green manure crop is an essential part of the reclamation process if and when possible. The use of super phosphate fertilizer, advocated as part of the reclamation process, will also help, as this fertilizer contains a significant amount of gypsum that, if the soils contain appreciable sodium, can offset any tendencies of the soil particles to disperse.

Soil fertility is poor. Phosphate, as well as nitrogen, needs to be incorporated to ensure root extension to lower layers. Manure, whilst an excellent conditioner, does not supply much phosphate. These comments apply for both sprinkler and gravity irrigation.

The whole question of sand movement and the need to establish windbreaks to protect irrigation developments needs not to be emphasized since research indicated that sand encroachment poses a real threat in the desert, semi-desert, arid and semi arid climatic zones of the Sudan.

In relation to soil salt and sodic content, a land capability-suitability for Agriculture production have been defined.

Table 5. Limitations used at subclass level

\begin{tabular}{l|l} 
letter & Denotation \\
\hline a & alkalinity \\
c & climate \\
d & Depth \\
e & Erosion \\
f & Fertility \\
g & Gravel \\
i & Inundation \\
p & Physical \\
s & Salinity \\
t & Topography \\
v & Vertisolic \\
w & Witness \\
\hline X & Pest and diseases
\end{tabular}

The soils of the area are classified with respect to their suitability after rating the different land qualities (Kevie and El-tom, 2003) as shown on Table 5.

Determining the suitability of the land to agriculture includes: the study of the soil, the available water resources, climate and vegetation cover. land capability However, many parametric systems e.g. productivity index, suitability index, productivity rating or suitability rating have made some attempts to answer such questions. All these systems depend on the effect of individual or land factor on the growth and yield of a certain crop or a certain group of crops. In addition, the combined effect of all these factors is computed mathematically to give the optimal land use. The factors used include: Soil texture, soil depth, soil consistence, depth to ground water, condition of the internal drainage, salinity, sodicity. soil $\mathrm{pH}$, percent calcium carbonat, eerosion hazards, slope (Klute, A. 1986). 
Then each factor is given a classification rating from 0 to100 for each crop. The classification ratings are multiplied to give the suitability or productivity index.

The suitability of the land to different crops is determined for field and horticultural crops (vegetables and fruits) according to Table 6.

Table 6. Land suitability to agricultural crops

\section{Suitability index}

for a crop or the average for a group of crops

$$
\begin{gathered}
0-20 \\
20-40 \\
40-60 \\
60-80 \\
80-100
\end{gathered}
$$

Degree of suitability

Unsuitable

Poor

Moderate

Good

Excellent

\section{CONCLUSIONS}

1. The level of both macro and micronutrients is low which is not unexpected of such soils that have developed under desert conditions with minimal weathering. This require an effective fertilizer program by addition of nitrogenous, phosphatic and potassic fertilizers, together with foliar spray of micro nutrient fertilizers for successful crop production. The organic carbon, and hence, organic matter is low as expected. Therefore, addition of organic manures should be entertained.

2. Composted organic manure is recommend to avoiding the invasion of weed and pathogenic microbes, however, raw fresh organic manures could be applied at the rate of three to five tons per feddan and chicken manure at the rate of 2 tons per feddan and well Green manure is also beneficial.

3. The infiltration rates of some soils are either high or low. This fact coupled with the undulated topography of the area, might suggest that modern irrigation systems e.g. drip, sprinkler, center pivot...etc should rather be adopted.

4. Salinity should be reclaimed through the conventional procedure e.g. deep ploughing, leaching and addition of organic manures.

5. The most of the agriculture crops might be applied in a specific crop rotation models, but only after the complete land reclamation measures and procedures took place.

\section{LITERATURE:}

[1] FAO (1976). A frame work for land evaluation. Soil Bulletin 32, Soil resources development anconservation services, Land and Water Development Division (AGLS), FAO HQ. Rome.

[2] FAO. (1985) Guidelines: Land evaluation for irrigated agriculture. Soils Bulletin 55. FAO, Rome Geological map of the Sudan (1981). Geological and Mineral Resources Department, Sudan.Resources Conservation Service, Ninth Edition, 2003, Washington D.C., USA.

[3] Van der Kevie (1976). Climatic Zones in the Sudan. Bulletin No. 27. Soil Survey Administration, Wad Medani Sudan.

[4] Whiteman, A. J. (1971). The Geology of the Sudan Republic, Clarendon Press, Oxford, United Kingdom. 
[5] Van der Kevie, W. and O. A. M. El-Tom (2003). Manual for Land Suitability Classification for Agriculture with Particular Reference to Sudan. Ministry of Science and Technology, Agric. Research and Technology Corporation. Land and Water Research Center, Wad-Medani, Sudan.

[6] Page, A. L.; Miller, R. H. and Ceaney, D. R. (1982). Methods of Soil Analysis. Part 2. Chemical and Microbiological Properties, 2nd edition, American Society of Agronomy, Inc., Soil Science Society of America, Inc., Madison, Wisconsin, USA.

[7] Klute, A. (1986). Methods of Soil Analysis Part I: Physical and Mineralogical Methods (2nd edition) American Society of Agronomy, Inc., Soil Science Society of America, Inc., Madison, Wisconsin, USA. 


\title{
EVALUACIJA OPTIMALNOG INDEKSA BILJNE PROIZVODNJE KAO REZULTATA KONTROLE SALINITETA I ALKALITETA ALUVIJALNIH ZEMLJIŠA ZAPADNE NILE NUBIAN DOLINE
}

\author{
Žeželj Branislav ${ }^{1}$, Hojka Zdravko \\ ${ }^{1}$ Megatrend, Fakultet za Biofarming, M. Tita 39, 24300 Bačka Topola, Srbija \\ 2"Meling” DOO, Marsala Tolbuhina 13, 11080, Belgrade-Zemun, Srbija \\ e-mail: melingzezelj@gmail.com
}

\section{ABSTRAKT}

Rastovrljive soli se uglavnom sreću u zaslanjenim zemljištima, uključujući one koje pripadaju alkalnim metalima $(\mathrm{Na}, \mathrm{K})$, kao i alkalnim zemljišnim elementima $(\mathrm{Ca}$, $\mathrm{Mg}$ ). Neke od ovih soli su rastorljive (karbonati, $\mathrm{Ca}$ i $\mathrm{Mg}$ ), slabo rastvorljive (Ca sulfati), dok su neke srednje do jako rastovorljive (hloridi, nitrati i bikarbonati $\mathrm{Ca}$ i $\mathrm{Mg}$ i sve soli $\mathrm{Na}$ i K). Površina predmetne studuje je podeljena unutar klasa saliniteta i alkalitetasodiciteta.

Kritičan nivo saliniteta (ECe) i alkaliteta (SAR) je odredio nivo tolerantnosti istih i njihov raspored i obim korišćenja uz primenu adekvatnog modela setvene structure u okviru površine predmetne studije. Uz predpostavku da je redukcija poterncijalnog prinosa od $25 \%$ maximalna u smislu tolerantnosti velikog dela poljoprivrednih kultura, onda je dozvoljeni novo ECe, ne veći od $12 \mathrm{dSm}^{-1}$ a dozvoljena vrednost SAR, ne veća od 24. Važno je istaći, da čak i pri takvim vrednostima ECe i SAR, nekih od osetljivih kultura mogu redukovati prinos i do 50\%. Sa druge strane, tolerantne culture će biti znatno manje izložene tako negativnom uticaju saliniteta I alkaliteta zemljišta.

Upravo biljne vrste različite tolerantnosti na visoku koncentaciju solu u zemljišu, takođe su različite tolerantnosti na visok sadržaj natrijuma u zemljištu. Rast biljaka i problem nihovog razvoja na zemljištima sa visokim sadržajem Na može imati nutritivno dejstvo (akomulacija natrijuma od stran biljaka), saglasno lošim fizičkim odnosima zemljišta. Biljke na sodifikovanim zemljištima uglavnom pokazuju ili pregorevanje ili sušenje tkiva stabljike i ivice listova sa progresivnim širenjem ka nervima-žilicama biljke. Kulture su različite osetljivosti na $\mathrm{Na}$, ali ako je nivo-sadržaj $\mathrm{Na}$ jako visok, sve biljene vrste su podložne ekstremno štetnom uticaju na njih rast i razvoj. Generalno se može reći da je Saja jako osetljiva u tom smislu, Kukuruz i Sorgum su umereno tolerantni, dok su Pšenica i Lucerka pokazuju veću tolerantnost. Nekoliko Sudanskih hibruda Sorguma su takođe veoma toleranti, pa se zato njihova primena preporučuje čak i na zemljištimasposobni čija je vrednost SAR iznad 50\%.

Shodno tome, studijom su evaluirane sve biljne vrste koje uspevaju u ovoj regiji, pa je na osnovu toga izvršena klasifikacija i selekcija onih koje se sa aspekta pogodnosti zemljišta i bilaka, studijom predlažu za nosioce modela setvene strukture i rotacije useva. Ovo tim pre što se radi o površinama od 16 miloina hektara Severnog Sudana.

Ključne reči: Kontrola salinitite, kontrola sodiciteta-natrijuma, reklamativna proizvodnja, ispiranje soli, pogodnost-sposobnost zemljista

Primljeno: 22. 04. 2019. god.

Prihvaćeno: 10. 05. 2019. god. 